\title{
MODEL PEMBELAJARAN TEMATIK BERBASIS KEARIFAN LOKAL
}

\author{
Nafia Wafiqni, M.Pd.; Siti Nurani, S.Pd.
}

Dosen di Fakultas Ilmu Tarbiyah dan Keguruan UIN Syarif Hidayatullah Jakarta; Guru di Madrasah Ibtidaiyah Negeri 1 Tangerang Selatan

Email: nafia.wafiqni@uinjkt.ac.id; sitinurani64@gmail.com

\begin{abstract}
ABSTRAK
Artikel ini bertujuan untuk mendeskripsikan: (1) Hakikat pembelajaran tematik; (2) Langkah-langkah pembelajaran tematik berbasis kearifan lokal; (3) Hakikat pendidikan kearifan lokal dalam lingkup pembelajaran tematik; (4) Tujuan dan pentingnya pendidikan kearifan lokal dalam lingkup pembelajaran tematik; serta (5) Pengajaran model tematik berbasis kearifan lokal. Artikel ini merupakan penelitian analisis konten/ meta analisis yang dilaksanakan melalui lima tahap, yaitu: (1) Pengumpulan data; (2) Penentuan sampel; (3) Pencatatan data; (4) Reduksi; dan (5) Penarikan kesimpulan. Sumber data dalam artikel ini adalah jurnal dan buku yang berkaitan dengan pembelajaran tematik dan pendidikan kearifan lokal. Selanjutnya, objek penelitian adalah proses adaptasi dan kaitannya dengan urgensi kearifan lokal dalam menjawab tantangan zaman. Kesimpulan artikel menunjukkan bahwa: (1) Pembelajaran tematik menggunakan tema-tema sebagai objek pembelajarannya; (2) Langkah-langkah model pembelajaran tematik berbasis kearifan lokal diantaranya guru terlebih dahulu membuat RPP, kemudiaan mensisipkan kearifan lokal pada konten materi; (3) Kearifan lokal dalam lingkup model pembelajaran tematik adalah nilai kebaikan yang terkandung dalam kebudayaan sebagai upaya mempertahankan identitas diri anak: (4) Tujuan dan pentingnya pendidikan kearifan lokal dalam lingkup pembelajaran tematik diantaranya untuk mempersiapkan generasi muda yang tanggap akan keunggulan lokal daerahnya; (5) Pengajaran model tematik berbasis kearifan lokal ini akan menjadi koneksi dalam
\end{abstract}


memahamkan anak untuk bertindak tepat dalam menghadapi tantangan global.

\section{Kata Kunci: Pembelajaran Tematik, Pendidikan Kearifan Lokal, Anak Usia Sekolah Dasar}

\section{A. PENDAHULUAN}

Pembelajaran merupakan suatu konsep dari dua dimensi kegiatan, yaitu belajarmengajar yang harus direncanakan dan diaktualisasikan, serta diarahkan pada penguasaan sejumlah kompetensi sebagai gambaran hasil belajar. ${ }^{1}$ Pembelajaran dapat pula dipandang sebagai, kegiatan guru secara terprogram untuk membantu siswa belajar secara aktif yang menekankan pada penyediaan sumber belajar. ${ }^{2}$ Pembelajaran sendiri memiliki berbagai macam model, contohnya dalam kurikulum 2013 saat ini model yang digunakan dalam pembelajaran tingkat sekolah dasar adalah model pembelajaran tematik.

Tematik dimaknai sebagai pembelajaran yang dirancang berdasarkan tema-tema tertentu. Dalam pembahasannya tema itu ditinjau dari berbagai mata pelajaran. Pembelajaran tematik menyediakan keluasan dan kedalaman implementasi kurikulum, ia juga menawarkan kesempatan yang sangat banyak pada siswa untuk memunculkan dinamika dalam pendidikan. Unit yang tematik adalah epitome dari seluruh bahasa pembelajaran yang menfasilitasi siswa untuk secara produktif menjawab pertanyaan yang dimunculkan sendiri dan memuaskan rasa ingin tahu dengan penghayatan secara alamiah tentang dunia di sekitar mereka. ${ }^{3}$

Teori pembelajaran ini, pada dasarnya dimotori oleh para tokoh Psikologi Gestalt, termasuk Piaget yang menekankan bahwa pembelajaran haruslah bermakna dan berorientasi pada kebutuhan dan perkembangan anak. ${ }^{4}$ Lebih lanjut, pembelajaran tematik juga dimaknai sebagai pembelajaran yang didasarkan pada sebuah tema sentral sebagai pengkait beberapa mata pelajaran dalam satu payung tema. ${ }^{5}$ Keterkaitan antar konsep dengan payung tema tentang kehidupan sehari-

1. Abdul Majid, Strategi Pembelajaran (Bandung, 2013), Hal. 5.

2. Ibid., Hal. 4.

3. Trianto, Mengembangkan Model Pembelajaran Tematik (Jakarta, 2010), Hal. 78.

4. Rusman, Model-Model Pembelajaran Mengembangkan Profesionalisme Guru (Jakarta: PT. Rajagrafindo Persada, 2010), Hal. 254.

5. Yanti H, Pembelajaran Tematik Mengggunakan Pendekatan Saintifik Dan Penilaian Otentik Untuk Mendukung Implementasi K13 (Jakarta: UIN Press, 2013), Hal. 6. 
hari, menjadikan strategi-strategi pembelajaran aktif dan kontekstual sangat relevan diterapkan pada pembelajaran tematik. Untuk mengkontekstualkan pembelajaran tematik tersebut, sebenarnya bisa dilakukan melalui penanaman nilai-nilai kearifan lokal di mana siswa berada.

Kearifan lokal pada dasarnya adalah nilai-nilai kebaikan dari budaya lokal dan sudah mendapat pengakuan oleh mayoritas masyarakat tentang kebaikannya. ${ }^{6}$ Lebih lanjut menurut Jamal Ma'mur, kearifan lokal atau keunggulan lokal adalah segala sesuatu yang menjadi ciri khas kedaerahan yang mencakup aspek ekonomi, budaya, teknologi informasi, komunikasi, ekolago, dan sebagainya. ${ }^{7}$ Dengan kata lain, kearifan lokal adalah sebuah investasi yang penting untuk memberikan siswa keterampilan, kemampuan dan kualitas diri dalam menghadapi dunia global tanpa meninggalkan identitas diri ataupun identitas bangsa.

Dan saat ini, model pembelajaran tematik telah menjadi isu utama dalam dunia pendidikan dan sudah ditekankan dalam kurikulum 2013 pada jenjang SD/MI. Namun harus diakui, implementasinya masih terkesan tumpang tindih. Internalisasi nilainilai kearifan lokal yang semestinya dimiliki oleh anak-anak bangsa masih bersifat parsial. Hal ini dikarenakan model pembelajaran tematik yang sering digunakan pada umumnya adalah model pembelajaran konvensional. Yang mana model pembelajaran tersebut cenderung pada teks book semata dan terfokus hanya di dalam kelas. Padahal salah satu kewajiban guru dalam mengajar adalah dapat menggunakan berbagai macam baik model, strategi, dan metode, yang dapat menarik minat siswa. Serta memanfaatkan sebaik mungkin sumber belajar yang ada di sekitar siswa (kearifan lokal), sebagai perwujudan dari salah satu karakteristik tematik (kontekstual).

Kearifan lokal sendiri adalah akar budaya Nasional yang mana nilai-nilai yang terkandung di dalamnya sarat dengan ajaran kebaikan. Dengan tersingkirnya kearifan lokal berakibat pada hilangnya sendi-sendi pembentuk moral dan jati diri anak bangsa. Di samping itu, juga mengakibatkan banyak ragam budaya yang mudah di claim oleh bangsa lain, karena ketidak pedulian generasi muda terhadap budayanya. Hal ini diperkuat dengan pernyataan Wakil Menteri Pendidikan dan Kebudayaan Bidang Kebudayaan, Wiendu Nuryanti yang mengatakan bahwa pemerintah Malaysia sudah

6. Sriyatin, Penanaman Dan Pengembangan Pendidikan Karakter Berbasis Kearifan Budaya Lokal Di Sdn Dersono Iii Pacitan (Program Pascasarjana Universitas Muhammadiyah: Surakarta, 2013), Hal. 10.

7. Moh Salimi, Pengembangan Pendidikan Karakter Bangsa Berbasis Kearifan Lokal Dalam Era Mea (Seminar Nasional Pendidikan, 2016), Hal. 114. 
tujuh kali mengklaim budaya Indonesia sejak 2007. Bahkan, tari zapin, rendang, gamelan, dan cendol pun tercatat dalam akta budaya Malaysia. ${ }^{8}$

Jika hal ini dibiarkan begitu saja, tentunya sangat membahayakan bagi kehidupan berbangsa dan bernegara. Siswa yang kurang memahami makna kearifan lokal juga cenderung kurang sensitif terhadap kemajemukan budaya setempatnya. Sehingga mereka bersikap apatis, dan mudah terpengaruh oleh terpaan kebudayaan asing dengan bungkus modernisme. Upaya mencetak generasi muda yang mampu tanggap terhadap tantangan global tersebut, hanya dapat dijawab dengan penyelenggaraan pendidikan yang berkualitas.

Pendidikan berkualitas adalah pendidikan yang mampu mengangkat nilainilai kearifan lokal yang dapat membantu siswa dalam proses pengembangan diri guna memperkuat identitas dan jati diri kebangsaan yang telah dimilikinya. Hal ini sesuai dengan pendapat Tilaar yang mengatakan bahwa pemahaman kearifan lokal dalam perspektif pendidikan menjadi modal dasar bagi proses pertumbuhan pendidikan. ${ }^{9}$ Senada dengan pendapat tersebut, Utari mengatakan bahwa untuk mengkontekstualkan pembelajaran salah satunya bisa dilakukan melalui penanaman nilai-nilai kearifan lokal di mana siswa berada. Pengenalan kearifan lokal yang ada di sekitar, penting sebagai bentuk pelestarian budaya lokal. ${ }^{10}$

Dengan demikian, model pembelajaran tematik berbasis kearifan lokal dirasa tepat dalam meng-cover kebutuhan peserta didik. Dengan mengintegrasikan tematik dan kearifan lokal, siswa secara tidak langsung dilatih untuk lebih peka terhadap lingkungannya. Pembelajaran tematik berbasis kearifan lokal ini juga mampu menanamkan konsep kepada siswa untuk menjaga kebhinekaan dan potensi kearifan lokal agar tidak tergerus oleh arus globalisasi sekaligus membantu siswa menghadapi tantangan yang semakin berkembang. Hal ini penting mengingat untuk mencintai NKRI siswa terlebih dahulu diajari mencintai budaya kearifan lokal daerahnya.

8. https:// ww w. google.com/Search?H1=Inid\&Source=Android browser $\&$ Ei=Pkflwsbnj8rwvgt_Loioca $\& Q=$ Kasus + Diklaim + Nya + Budaya+Indonesia\&Oq=Kasus+Diklaim+ Nya+Budaya+Indonesia (Tempo.co).

9. Sularso, Revitalisasi Kearifan Lokal Dalam Pendidikan Dasar, Jurnal Pendidikan Sekolah Dasar Vol. 2, No. 1, 2016, Hal. 77.

10. Moh. Farid Nurul Dkk, Pengembangan Modul Pembelajaran Tematik Terpadu Berbasis Kearifan Lokal Kabupaten Sumenep Kelas Iv Subtema Lingkungan Tempat Tinggalku, Jurnal Pendidikan, Vol. 2, No.10, 2017, t.t., Hal. 1292. 


\section{B. METODE PENELITIAN}

Metode penelitian yang digunakan pada penelitian ini adalah metode analisis konten/ meta analisis. Analisi Konten merupakan suatu studi yang menggabungkan hasil banyak studi orisinal, sistematis, terencana, observasi retrospektif, dengan analisis statistika yang formal. ${ }^{11}$ Metode ini dilaksanakan melalui lima tahap, yaitu: (1) Pengumpulan data/ Latar belakang; (2) Pertanyaan penelitian/ Penentuan sampel; (3) Hipotesis yang akan diuji/ pencatatan data; (4) Reduksi dan (5) Tujuan dan manfaat penelitian/ Penarikan kesimpulan.

Sumber data dalam artikel ini adalah jurnal dan buku yang berkaitan dengan pembelajaran tematik dan pendidikan kearifan lokal. Selanjutnya, objek penelitian adalah proses adaptasi dan kaitannya dengan urgensi kearifan lokal dalam menjawab tantangan zaman.

\section{HASIL PENELITIAN DAN PEMBAHASAN}

\section{Hakikat Pembelajaran Tematik}

Pembelajaran tematik adalah salah satu model dalam pembelajaran terpadu yang merupakan suatu sistem pembelajaran yang memungkinkan siswa aktif menggali dan menemukan konsep serta prinsip keilmuan secara holistik, bermakna, autentik dan kontekstual. ${ }^{12}$ Pendapat lain mengatakan, Integrated Thematic Instruction-based curricula stresses the integration of all disciplines to present students with learning experiences that are based on real-world application and structured to encourage higher-order learning. ${ }^{13}$ Lebih lanjut, Trianto mengatakan bahwa pembelajaran tematik adalah pembelajaran yang menggunakan tema untuk mengaitkan beberapa mata pelajaran sehingga dapat memberikan pengalaman bermakna kepada peserta didik. ${ }^{14}$

Melalui pelaksanaan model pembelajaran tematik siswa dapat memperoleh pengalaman langsung dan terlatih untuk dapat menemukan sendiri berbagai

11. (file://C:/Users/ACER/Downloads/sss155_slide_meta_analisis.pdf).

12. Fitri Indriani, Kompetensi Pedagogik Mahasiswa Dalam Mengelola Pembelajaran Tematik Integratif Kurikulum 2013 Pada Pengajaran Micro Di Pgsd Uad Yogyakarta, Jurnal Kependidikan, Vol. 2, No. 2, Hal. 88.

13. Anwar Novianto, Analisis Buku Teks Muatan Tematik Integratif, Scientific Approach, Dan Authentic Assessment Sekolah Dasar, Jurnal Kependidikan, Vol. 45, No. 1, 2015, Hal. 3.

14. Srikandi Oktaviani, Pengembangan Bahan Ajar Tematik Dalam Implementasi Kurikulum 2013 Kelas 1 Sekolah Dasar, Jurnal Pendidikan Dasar, Vol. 9 No. 2, 2017, Hal. 94. 
pengetahuan, konsep, sikap, keterampilan, yang dipelajari secara holistik, bermakna, otentik, aktif, dan menyenangkan. ${ }^{15}$ Senada dengan pendapat tersebut, Depdikbud juga mengatakan bahwa karakteristik pembelajaran tematik yaitu: (1) Holistic, (2) Bermakna, (3) Autentik, (4) Aktif, dan (5) Integrative. ${ }^{16}$

Dengan demikian, pembelajaran tematik merupakan pembelajaran yang menggunakan tema-tema sebagai objek pembelajarannya. Tema-tema sentral tersebut, kemudian dikerucutkan menjadi beberapa subtema. Hal ini tentunya membuat pembelajaran menjadi utuh (holistic). Ditambah dengan menghadirkan materi yang berbasis kearifan lokal ini maka penguasaan konsep siswa akan semakin baik dan meningkat. Karena pembelajaran tak lagi bersifat teksbooks melainkan kontekstual, dan tentunya hal ini dapat mendorong kegiatan pembelajaran menjadi lebih bermakna.

\section{Langkah-langkah Pembelajaran Tematik}

Alur atau langkah-langkah dalam mengembangkan rencana pelaksanaan pembelajaran tematik meliputi tujuh tahap, yaitu:

a) Menetapkan pelajaran yang akan dipadukan dengan kearifan lokal

b) Mempelajari KD pada kelas dan semester yang sama

c) Menentukan indikator dan hasil belajar dalam setiap mata pelajaran dan dikaitkan dengan kearifan lokal yang ada

d) Memilih dan menetapkan tema pemersatu dengan menggunakan kearifan lokal sebagai media konkrit dalam pembelajaran

e) Membuat matriks hubungan kompetensi dasar dan tema pemersatu serta memperhatikan esensi dari kearifan lokal pada materi

f) Menyusun silabus pembelajaran tematik

g) Menyusun satuan pelajaran pembelajaran tematik. ${ }^{17}$

Pendapat lain menyebutkan, pelaksanaan kegiatan pembelajaran tematik yang sesuai dengan bahan sosialisai kurikulum 2013 oleh Kemendikbud, ada 4 tahapan yakni: (1) Menentukan tema, (2) Mengintegrasikan tema dengan kurikulum yang

15. Rusman, Model-Model Pembelajaran Mengembangkan Profesionalisme Guru, Edisi Kedua, (Jakarta: Rajagrafino Persada, 2012), Hal. 8.

16. Asep Ediana L, Pembelajaran Tematik Dalam Kajian Teoritik Dan Praktik (Jakarta: UIN, 2012), Hal 10-11.

17. Yanti H, Pembelajaran Tematik Mengggunakan Pendekatan Saintifik Dan Penilaian Otentik Untuk Mendukung Implementasi K13, Hal. 194. 
sesuai dan berlaku dengan mengedepankan dimensi sikap, pengetahuan, dan keterampilan, (3) Mendesain RPP yang mencakup ruang lingkup tema, dan (4) Melaksanakan aktivtitas pembelajaran siswa belajar secara aktif. ${ }^{18}$

Dengan demikian dalam pelaksanaan pembelajaran tematik, guru terlebih dahulu membuat RPP (Rancangan Pelaksanaan Pembelajaran) yang mana memuat aspek-aspek persiapan (pengkondisian siswa), pelaksanaan (inti) dan penutup (refleksi). Dalam RPP tersebut, guru mesisipkan pendidikan kearifan lokal dalam kegiatan pembelajarannya. Misalnya tema "Daerah Tempat Tinggalku" subtema "Lingkungan Tempat Tingggalku". Pada tema ini, materi pembelajaran meliputi materi:

IPA

: 3.4. Hakikat gaya dan gerak

Bahasa Indonesia : 3.9. Hakikat cerita fiksi

PPKn : 3.3. Keberagam karakteristik individu

IPS : 3.3. Kegiatan ekonomi masyarakat, dan

SBdP : 3.2. Tanda tempo dan tinggi rendah nada ${ }^{19}$

Maka pendidikan kearifan lokal, dapat di subtansikan ke dalam materi tersebut dengan melakukan kegiatan berikut:

1) Pada materi IPA guru dapat meminta siswa mendorong dan menarik meja (sebagai contoh konkrit), siswa dapat mempraktikkan gaya dorongan dan tarikan dalam kehidupan sehari-hari, serta siswa dapat mengetahui perubahan gerak akibat gaya.

2) Pada materi Bahasa Indonesia guru dapat meminta siswa melakukan kegiatan mencari tahu pengertian, jenis-jenis dan ciri-ciri cerita fiksi, siswa dapat menjelaskan secara tertulis maupun lisan (Dengan ini, siswa dikenalkan dengan cerita-cerita fiksi yang ada di Indonesia misal legenda malin kundang dan siswa juga dilatih untuk gemar membaca buku-buku cerita Indonesia).

3) Pada materi PPKn siswa dapat melakukan kegiatan mengidentifikasi karakteristik individu anggota keluarganya (Hal ini sebagai pembelajaran mengenal identitas diri).

18. Hendra Jati Puspita, Implementation Of Integrated Thematic Learning In Class Vb Sd Negeri Tegalrejo 1 Yogyakarta, Jurnal Pendidikan Guru Sekolah Dasar, Edisi 9, 2016, Hal 890.

19. Ari Subekti, Daerah Tempat Tinggalku-Edisi Revisi Buku Guru Kelas Iv (Jakarta: Kementerian Pendidikan Dan Kebudayaan, 2017), Hal. 5. 
4) Pada materi IPS siswa dapat melakukan kegiatan mengamati penduduk di lingkungan tempat tinggal, siswa mampu mengidentifikasi jenis pekerjaan terkait dengan kegiatan ekonomi di lingkungan tempat tinggalnya (Mengenalkan kearifan lokal yang ada di daerahnya dan membentuk sikap kepedulian akan hal tersebut).

5) Pada materi SBdP siswa dapat melakukan kegiatan menyanyikan lagu daerah, siswa dapat menyanyikan lagu dengan tempo dan tinggi rendah nada yang tepat (Mengenalkan kearifan budaya yang dimiliki Indonesia).

Disamping itu, guru juga memiliki peran untuk menentukan sumber belajar yang akan digunakan untuk menunjang kegiatan pembelajaran. Sumber belajar yang dipilih harus memenuhi karakteristik pembelajaran tematik, yaitu holistik, bermakna, autentik dan aktif. ${ }^{20}$ Untuk itu, sumber belajar yang tepat digunakan adalah sumber belajar yang dekat dengan lingkungan peserta didik/ kearifan lokal. Kearifan lokal dianggap tepat digunakan, karena model ini mengajarkan peserta didik untuk selalu dekat dengan situasi konkrit yang mereka hadapi sehari-hari.

Model ini juga turut membantu pemberdayaan keterampilan peserta didik, serta potensi lokal pada lingkungannya. Sehingga merangsang tumbuhnya kepekaan pada diri siswa terhadap kekayaan lingkungannya. Secara tidak langsung siswa juga dilatih untuk mendapatkan gambaran yang utuh atas identitas dirinya dan negaranya. Hal ini dimaksudkan agar pembelajaran yang berlangsung sesuai dengan koridor yang seharusnya sehingga tujuan pembelajaran mudah tercapai.

\section{Hakikat Pendidikan Kearifan Lokal}

Di dalam kalamullah tepatnya Q.S al-Baqarah ayat 269, kata kearifan (hikmah) dan ilmu ('ilm) sering diidentikkan, meskipun terdapat perbedaan substansi. Istilah hikmah atau kearifan sesungguhnya merujuk pada level atau tingkat kesadaran tertinggi yang berada di atas pengetahuan. Atau dengan kata lain, menegaskan bahwa orang yang diberi hikmah telah memperoleh kebaikan yang banyak. Senada dengan pendapat tersebut, Rahyono mengatakan bahwa kearifan lokal merupakan kecerdasan manusia yang dimiliki oleh kelompok etnis tertentu yang diperoleh melalui pengalaman masyarakat. ${ }^{21}$ Kearifan lokal juga diartikan

20. Dindin Ridwanudin, Bahasa Indonesia (Jakarta: Uin Press, t.t.), Hal. 38.

21. Ahmal, Kearifan Lokal Dan Pendidikan IPS: Studi Peduli Lingkungan Dalam Hutan Larangan Masyarakat Adat Kampar, Sosio Didaktika: Social Science Education Journal, 4 (1), 2017, Hal. 63. 
sebagai "Knowledge systems which oriented to nature's language at specific area is called local wisdom. Local wisdom is the positive behavior of man connecting with nature and the surrounding environment. Local wisdom can be understood as a local idea that is wise, full of wisdom, good-value, which is ingrained and observed by the people." 22

Esensi dari kearifan lokal sendiri sejatinya adalah nilai-nilai kebaikan, kebijaksanaan, kedewasaan memandang segala sesuatu hal dan kemampuan menerjemahkan secara baik setiap persoalan yang bertumpu pada budaya lokal. ${ }^{23}$ Lebih lanjut Naritoom, juga merumuskan definisi local wisdom, yaitu “... is the knowledge that discovered or acquiredby lokal people through the accumulation of experiences in trials and integrated with the understanding of surrounding nature and culture. Local wisdom is dynamic by function of created local wisdom and connected to the global situation." 24

Dengan demkian, pendidikan kearifan lokal adalah nilai-nilai kebaikan yang terkandung dalam kebudayaan masyarakat sebagai upaya membangun identitas dan karater peserta didik dalam menghadapi tantangan zaman. Lebih lanjut Kuntoro mengatakan bahwa kata kearifan lokal digunakan untuk mengindikasikan adanya suatu konsep bahwa dalam kehidupan sosial-budaya terdapat suatu keluhuran, ketinggian nilai-nilai, kebaikan dan keindahan yang dihargai oleh warga masyarakat sehingga digunakan sebagai pedoman untuk membangun pola hubungan di antara warga/ sebagai dasar untuk membangun tujuan hidup mereka yang ingin direalisasikan. ${ }^{25}$

Pendidikan kearifan lokal dapat melatih peserta didik agar terbiasa memiliki kepedulian dan rasa tanggung jawab dalam menjaga, memanfaatkan serta melestarikan lingkungan dan budayanya. Karena pembelajaran berbasis kearifan lokal ini menuntut peserta didik untuk belajar dari kehidupan dan pengalaman

22. Dahliani Dkk, Local Wisdom In Built Environment In Globalization Era, International Journal Of Education And Research, Vol. 3, No. 6, 2015, Hal. 157.

23. Ali Harsojo, Membangun Karakter Berkearifan Lokal Dalam Bingkai Pendidikan Persekolahan, Vol. 4, No. 1, 2013, Hal. 27.

24. Suswandari, Pemahaman Sejarah, Budaya Dan Kearifan Lokal Etnik Betawi Pada Guru Sekolah Dasar Di Wilayah Dki Jakarta, Prosiding Kolokium Doktor Dan Seminar Hasil Penelitian Hibah, 2016, Hal. 37.

25. Rukiyati, Dkk, Model Pendidikan Karakter Berbasis Kearifan Lokal Pada Sekolah Dasar Di Bantul Yogyakarta, Jurnal Pendidikan Karakter, No. 1, 2016, Hal. 123. 
nyata di sekolah maupun di masyarakat ${ }^{26}$ Model ini juga turut mempertahankan identitas diri peserta didik atau rasa nasionalisme yang ditanamkan dalam kegiatan pembelajaran tematik berbasis kerifan lokal. Sehingga melalui penanaman pembiasaan tersebut, wawasan kearifan lokal akan tertanam pada diri setiap siswa.

\section{Tujuan dan Pentingnya Pendidikan Kearifan Lokal}

Tujuan pendidikan berbasis kearifan lokal adalah agar siswa mengetahui keunggulan lokal daerah di mana dia tinggal, memahami berbagai aspek yang berhubungan dengan keunggulan lokal daerah tersebut, selanjutnya siswa mampu mengolah sumber daya, terlibat dalam pelayanan/ jasa atau kegiatan lainnya, sehingga memperoleh pendapatan dan melestarikan budaya/ tradisi/ sumber daya yang menjadi ungulan daerah serta mampu bersaing secara nasional maupun global. ${ }^{27}$

Disamping itu, secara umum kearifan lokal memiliki ciri dan fungsi sebagai berikut: (1) sebagai penanda identitas; (2) sebagai elemen perekat kohesi sosial; (3) sebagai unsur budaya yang tumbuh dari bawah, eksis dan berkembang dalam masyarakat; (4) berfungsi memberikan warna kebersamaan bagi komunitas tertentu; (5) dapat mengubah pola pikir dan hubungan timbal balik individu dan kelompok dengan meletakkannya di atas common ground; (6) mampu terbangunnya kebersamaan dan mekanisme bersama untuk mempertahankan diri dari terjadinya gangguan atau perusak solidaritas kelompok. ${ }^{28}$

Dengan kata lain tujuan pendidikan kearifan lokal adalah mempersiapkan generasi muda yang tanggap akan keunggulan lokal daerah di mana dia tinggal, serta memiliki identitas diri yang berlandasan dengan identitas bangsa dan negaranya. Selanjutnya, seperti kita ketahui pendidikan kearifan lokal penting diterapkan dalam pembelajaran tematik selain karena melihat dari tujuan pendidikan tersebut, pendidikan ini juga merupakan manivestasi bangsa, dalam mengahadapi persaingan secara nasional maupun global. Hal ini diperkuat dengan pendapat yang mengatakan bahwa, Local Wisdom can be either local knowledge,

26. Rista Apriliya D., "Penerapan Strategi Pembelajaran Kontekstual Berbasis Kearifan Lokal Pada Mata Pelajaran IPS Di SDN Duduklor Kecamatan Glagah Kabupaten Lamongan, Jurnal Seminar Nasional Pendidikan,” 2016, Hal. 108.

27. Mukminan, Perspektif Teori Dan Praktik Implementasi Sekolah Berbasis Keunggulan Lokal. (Makalah Semnas Univ. Samawa Sumbar), 2011, Hal. 21.

28. Unga Utari Dkk, Pembelajaran Tematik Berbasis Kearifan Lokal Di Sekolah Dasar Dalam Menghadapi Masyarakat Ekonomi Asean (Mea), Vol.1, No.1, 2016, Hal. 42. 
local skills, local intelligence, local resources, local social processes, values or local norms and local customs. The importance integrated local wisdom in learning, One of them by developed an innovative learning model that can not only improve the competence of the 21st century, but also to maintain the nation's cultural values. ${ }^{29}$

Lebih lanjut Taylor dkk, explained that local knowledge is an important value in supporting investigation technique, development policy, and effective use in the process of environmental decision making. Local wisdom is the life value order inherited from one generation to another in the form of religion, culture or custom that is commonly spoken in nature in a society's social system. The presence of local wisdom in the society is the result of adaptation process to a usually inhabited environment in which interaction often occurs from one generation to another in a very long period of time. ${ }^{30}$ Maka dengan mengenalkan keragaman kearifan lokal yang dimiliki tiap daerah, peserta didik akan semakin paham makna perbedaan. Dengan perbedaan peserta didik akan semakin paham makna kebersamaan sehingga timbuhlah sikap toleransi dalam diri peserta didik. Di samping itu tentunya, untuk mencintai NKRI peserta didik terlebih dahulu dikenalkan dan ditumbuhkan rasa kecintaannya terhadap kearifan lokal yang dimilikinya. Pembelajaran tematik berbasis kearifan lokal juga dirasa tepat digunakan karena dengan model ini mampu meningkatkan minat peserta didik jauh lebih baik dibandingkan dengan penbelajaran terfokus pada teks book. Paulo Freire, filsuf pendidikan dalam bukunya, Cultural Action for Freedom menyebutkan, dengan dihadapkan pada problem dan situasi konkret yang dihadapi, peserta didik akan semakin tertantang untuk menanggapinya secara kritis. ${ }^{31}$

\section{Pengajaran Model Tematik Berbasis Kearifan Lokal}

Kearifan lokal merupakan aset bangsa, di mana terdapat kekayaan sumber daya baik dari alam maupun buatan yang mana setiap daerah memiliki keistimewaannya tersendiri. Salah satu upaya mengembangkan kearifan lokal

29. Ika Nurani, Dkk, Elsii Learning Model Based Local Wisdom To Improve Students Problem Solving Skills And Scientific Communication, International Journal Of Education And Research, Vol. 5 No. 1, 2017, Hal. 42.

30. Leo Agung S, The Development Of Local Wisdom-Based Social Science Learning Model With Bengawan Solo As The Learning Source, American International Journal Of Social Science, Vol. 4, No. 4, 2015, Hal. 52.

31. Nadlir, Urgensi Pembelajaran Berbasis Kearifan Lokal, Jurnal Pendidikan Agama Islam, Vol. 02, No. 02, 2014, Hal. 315. 
yaitu dengan mengenalkannya pada generasi muda. Penanaman potensi lokal bisa dilakukan dengan mengintegrasikan pada pembelajaran di sekolah. Namun karena cakupan kearifan lokal cukup luas, maka dibutuhkan model pembelajaran yang mampu mewadahinya. Model pembelajaran tersebut adalah model pembelajaran tematik berbasis kearifan lokal. Kemendiknas menguraikan hasil analisis tentang penentuan jenis keunggulan lokal dalam implementasinya di sekolah, yang meliputi: (1) Inventarisasi aspek potensi keunggulan lokal, (2) Analisis kondisi internal sekolah, dan (3) Analisis lingkungan eksternal sekolah. ${ }^{32}$ Atau dengan kata lain pembelajaran kearifan lokal ini merupakan suatu tindakan yang mencakup dari cipta, rasa dan karya masyarakat dalam mengatasi permasalahan setempat.

Pembelajaran melalui lingkungan/ kearifan lokal memberikan nilai lebih pada pengembangan kecakapan hidup peserta didik. Kecakapan hidup yang dimiliki siswa melalui pembelajaran lingkungan ini akan membangun karakter peserta didik yang kreatif, bertanggung jawab, dan mandiri. ${ }^{33}$ Terdapat tiga komponen utama pengajaran kearifan lokal, yakni: (1) Pengintegrasian pendekatan pembelajaran kecakapan berpikir arif (wise thinking skills); (2) Adanya iklim atau budaya sekolah sebagai wadah persemaian yang membiasakan sikap, pikiran dan tindakan yang memanifestasikan kearifan; 3) Komitmen guru sebagai teladan. ${ }^{34}$

Hasil temuan di atas sesuai dengan penelitian yang dilakukan oleh Degeng dan Sudana Nyoman hasil penelitian yang dihasilkan adalah nilai-nilai kearifan lokal akan membantu siswa dalam memahami setiap konsep dalam materi. ${ }^{35}$ Kearifan lokal juga merupakan modal utama masyarakat dalam membangun dirinya tanpa merusak tatanan sosial yang adatif dengan lingkungan alam sekitarnya. ${ }^{36}$

32. Dian Bakhtiar, Bahan Ajarberbasis Kearifan Lokal Terintegrasi Stm (Sains, Teknologi, Dan Masyarakat) Pada Mata Pelajaran Fisika, Seminar Nasional Pendidikan, Vol. 1, 2016, Hal. 656.

33. Imam Suyitno, Pengembangan Pendidikan Karakter Dan Budaya Bangsa Berwawasan Kearifan Lokal, Jurnal Pendidikan Karakter, No. 1, 2012, Hal 10.

34. Al Musanna, Artikulasi Pendidikan Guru Berbasis Kearifan Lokal Untuk Mempersiapkan Guru Yang Memiliki Kompetensi Budaya, Jurnal Pendidikan Dan Kebudayaan, Vol. 18, No. 3, 2012, Hal. 335.

35. Lis Setyaningrum, Manajemen Kelas Berbasis Kearifan Lokal Di Sd Muhammadiyah 24 Gajahan Surakarta, Skripsi Pada Universitas Muhammadiyah Surakarta, 2017, Hal. 10.

36. Nuraini A, Mengembangkan Karakter Peserta Didik Berbasis Kearifan Lokal Melalui Pembelajaran di Sekolah, Jurnal Pendidikan Sosiologi dan Humaniora, Vol. 3, No. 2, 2012, Hal. 112. 
Sehingga bekal pengetahuan yang diperoleh siswa tidak hanya sampai pada sebatas pengetahuan saja, tetapi juga dapat diimplementasikan langsung dalam kehidupan sehari-hari peserta didik (pembelajaran bermakna).

Dengan demikian, pembelajaran tematik berbasis kearifan lokal akan menjadi koneksi dalam memahamkan siswa untuk bertindak tepat dalam menghadapi tantangan global. Peradaban yang tidak hanya menuntut manusia sekedar serba tahu melainkan apa yang dapat dikontribusikan guna memajukan negara. Membekali generasi muda dengan pendidikan kearifan lokal, sama hal nya dengan membekali generasi muda dengan kepribadian yang kuat, identitas diri, dan nilai-nilai yang baik serta relevan dengan program sekolah. Agar pendidikan tidak hanya dalam pengembangan pengetahuan saja, melainkan ketrampilan, wawasan kearifan lokal dan membentuk kepribadian siswa yang sesuai dengan identitas bangsa.

\section{SIMPULAN}

Berdasarkan paparan teori di atas dapat ditarik simpulan sebagai berikut:

1. Hakikat model pembelajaran tematik adalah pembelajaran yang menggunakan tema-tema sebagai objek pembelajarannya, dan dengan menghadirkan materi yang berbasis kearifan lokal ini dapat mendorong kegiatan pembelajaran menjadi lebih bermakna, karena pembelajaran tak lagi bersifat teksbook melainkan kontekstual.

2. Langkah-langkah model pembelajaran tematik berbasis kearifan lokal diantaranya guru terlebih dahulu membuat RPP yang mana memuat aspek-aspek persiapan (pengkondisian siswa), pelaksanaan (inti) dan penutup (refleksi). Dalam pembuatan RPP, guru mesisipkan pendidikan kearifan lokal baik dalam konten materi maupun pada proses kegiatan pembelajaran, dengan menghadirkan sumber belajar yang dekat dengan lingkungan peserta didik/ kearifan lokal.

3. Hakikat kearifan lokal dalam lingkup model pembelajaran tematik adalah nilainilai kebaikan yang terkandung dalam kebudayaan sebagai upaya mempertahankan identitas diri peserta didik atau rasa nasionalisme yang sengaja ditanamkan dalam kegiatan pembelajaran tematik. Sehingga melalui penanaman pembiasaan tersebut, wawasan kearifan lokal akan tertanam pada diri setiap siswa.

4. Tujuan dan pentingnya pendidikan kearifan lokal dalam lingkup pembelajaran tematik diantaranya untuk mempersiapkan generasi muda yang tanggap akan keunggulan lokal daerah di mana dia tinggal, serta memiliki identitas diri yang berlandasan dengan identitas bangsa dan negaranya. Selanjutnya, pendidikan ini 
penting diterapkan dalam pembelajaran tematik selain karena melihat dari tujuan pendidikan tersebut, pendidikan ini juga merupakan manivestasi bangsa, dalam mengahadapi persaingan secara nasional maupun global.

5. Penanaman potensi lokal pada anak dapat dilakukan dengan mengintegrasikan pada pembelajaran tematik. Pengajaran model tematik berbasis kearifan lokal ini akan menjadi koneksi dalam memahamkan anak untuk bertindak tepat dalam menghadapi tantangan global serta mencetak peradaban yang tidak hanya menuntut manusia sekedar serba tahu melainkan apa yang dapat dikontribusikan guna memajukan negaranya.

\section{E. DAFTAR PUSTAKA}

Agung S, Leo. The Development Of Local Wisdom-Based Social Science Learning Model With Bengawan Solo As The Learning Source, American International Journal Of Social Science, Vol. 4, No. 4, 2015.

Ahmal. Kearifan Lokal Dan Pendidikan IPS: Studi Peduli Lingkungan Dalam Hutan Larangan Masyarakat Adat Kampar, Sosio Didaktika: Social Science Education Journal, 4 (1), 2017.

Apriliya D, Rista. Penerapan Strategi Pembelajaran Kontekstual Berbasis Kearifan Lokal Pada Mata Pelajaran IPS Di SDN Duduklor Kecamatan Glagah Kabupaten Lamongan, Jurnal Seminar Nasional Pendidikan, 2016.

Bakhtiar, Dian. "Bahan Ajar Berbasis Kearifan Lokal Terintegrasi STM (Sains, Teknologi, Dan Masyarakat) Pada Mata Pelajaran Fisika, Seminar Nasional Pendidikan, Vol. 1," 2016.

Dahliani Dkk. "Local Wisdom In Built Environment In Globalization Era, International Journal Of Education And Research, Vol. 3, No. 6,” 2015.

Ediana L, Asep. Pembelajaran Tematik Dalam Kajian Teoritik Dan Praktik. Jakarta: UIN, 2012.

“(file:///C:/Users/ACER/Downloads/sss155_slide_meta_analisis.pdf)," t.t.

Harsojo, Ali. "Membangun Karakter Berkearifan Lokal Dalam Bingkai Pendidikan Persekolahan, Vol. 4, No. 1,” 2013.

"https://www.google.com/Search?H1=Inid\&Source=Android browser\&Ei=Pkflwsbnj8rwvgt_Loioca\&Q=Kasus+Diklaim + Nya +Budaya+Indonesia\&Oq=Kasus+Diklaim+Nya+Budaya+Indonesia (Tempo. co)," t.t. 
Ika Nurani, Dkk. "Elsii Learning Model Based Local Wisdom To Improve Students Problem Solving Skills And Scientific Communication, International Journal Of Education And Research, Vol. 5 No. 1,” 2017.

Indriani, Fitri. Kompetensi Pedagogik Mahasiswa Dalam Mengelola Pembelajaran Tematik Integratif Kurikulum 2013 Pada Pengajaran Micro Di Pgsd Uad Yogyakarta, Jurnal Kependidikan, Vol. 2, No. 2, t.t.

Majid, Abdul. Strategi Pembelajaran. Bandung, 2013.

Moh. Farid Nurul Dkk. Pengembangan Modul Pembelajaran Tematik Terpadu Berbasis Kearifan Lokal Kabupaten Sumenep Kelas Iv Subtema Lingkungan Tempat Tinggalku, Jurnal Pendidikan, Vol. 2, No.10, 2017, t.t.

Mukminan. "Perspektif Teori Dan Praktik Implementasi Sekolah Berbasis Keunggulan Lokal. (Makalah Semnas Univ. Samawa Sumbar),” 2011.

Musanna, A1. "Artikulasi Pendidikan Guru Berbasis Kearifan Lokal Untuk Mempersiapkan Guru Yang Memiliki Kompetensi Budaya, Jurnal Pendidikan Dan Kebudayaan, Vol. 18, No. 3,” 2012.

Nadlir. "Urgensi Pembelajaran Berbasis Kearifan Lokal, Jurnal Pendidikan Agama Islam, Vol. 02, No. 02,” 2014.

Nafia Wafiqni, M.Pd adalah Dosen Jurusan Pendidikan Guru Madrasah Ibtidaiyah, Fakultas Ilmu Tarbiyah dan Keguruan, Universitas Islam Negeri Syarif Hidayatullah Jakarta. (email: nafia.wafiqni@uinjkt.ac.id), t.t.

Novianto, Anwar. "Analisis Buku Teks Muatan Tematik Integratif, Scientific Approach, Dan Authentic Assessment Sekolah Dasar, Jurnal Kependidikan, Vol. 45, No. 1,” 2015.

Nuraini A. "Mengembangkan Karakter Peserta Didik Berbasis Kearifan Lokal Melalui Pembelajaran di Sekolah, Jurnal Pendidikan Sosiologi dan Humaniora, Vol. 3, No. 2," 2012.

Oktaviani, Srikandi. "Pengembangan Bahan Ajar Tematik Dalam Implementasi Kurikulum 2013 Kelas 1 Sekolah Dasar, Jurnal Pendidikan Dasar, Vol. 9 No. $2, " 2017$.

Puspita, Hendra Jati. "Implementation Of Integrated Thematic Learning In Class Vb Sd Negeri Tegalrejo 1 Yogyakarta, Jurnal Pendidikan Guru Sekolah Dasar, Edisi 9," 2016.

Ridwanudin, Dindin. Bahasa Indonesia. Jakarta: UIN Press, t.t. 
Rukiyati, Dkk. "Model Pendidikan Karakter Berbasis Kearifan Lokal Pada Sekolah Dasar Di Bantul Yogyakarta, Jurnal Pendidikan Karakter, No. 1,” 2016.

Rusman. Model-Model Pembelajaran Mengembangkan Profesionalisme Guru. Jakarta: Pt Rajagrafindo Persada, 2010.

- Model-Model Pembelajaran Mengembangkan Profesionalisme Guru, Edisi Kedua,. Jakarta: Rajagrafino Persada, 2012.

Salimi, Moh. Pengembangan Pendidikan Karakter Bangsa Berbasis Kearifan Lokal Dalam Era Mea. Seminar Nasional Pendidikan, 2016.

Setyaningrum, Lis. "Manajemen Kelas Berbasis Kearifan Lokal Di Sd Muhammadiyah 24 Gajahan Surakarta, Skripsi Pada Universitas Muhammadiyah Surakarta," 2017.

Siti Nurani, S.Pd adalah Guru Kelas Madrasah Ibtidaiyah Negeri 1 Tangsel. (email: sitinurani64@gmail.com), t.t.

Sriyatin. Penanaman Dan Pengembangan Pendidikan Karakter Berbasis Kearifan Budaya Lokal Di Sdn Dersono Iii Pacitan. Program Pascasarjana Universitas Muhammadiyah: Surakarta, 2013.

Subekti, Ari. Daerah Tempat Tinggalku-Edisi Revisi Buku Guru Kelas IV. Jakarta: Kementerian Pendidikan Dan Kebudayaan, 2017.

Sularso. Revitalisasi Kearifan Lokal Dalam Pendidikan Dasar, Jurnal Pendidikan Sekolah Dasar Vol. 2, No. 1, 2016.

Suswandari. "Pemahaman Sejarah, Budaya Dan Kearifan Lokal Etnik Betawi Pada Guru Sekolah Dasar Di Wilayah DKI Jakarta, Prosiding Kolokium Doktor Dan Seminar Hasil Penelitian Hibah,” 2016.

Suyitno, Imam. "Pengembangan Pendidikan Karakter Dan Budaya Bangsa Berwawasan Kearifan Lokal, Jurnal Pendidikan Karakter, No. 1,” 2012.

Trianto. Mengembangkan Model Pembelajaran Tematik. Jakarta, 2010.

Unga Utari Dkk. "Pembelajaran Tematik Berbasis Kearifan Lokal Di Sekolah Dasar Dalam Menghadapi Masyarakat Ekonomi Asean (Mea), Vol.1, No.1,” 2016.

Yanti H. Pembelajaran Tematik Mengggunakan Pendekatan Saintifik Dan Penilaian Otentik Untuk Mendukung Implementasi K13. Jakarta: Uin Press, 2013. 